DOI:10.17951/h.2018.52.3.115-125

\begin{tabular}{lcc}
\hline & A N N A L E S \\
UNIVERSITATIS MARIAE CURIE-SKŁODOWSKA \\
LUBLIN - POLONIA \\
VOL. LII, 3 & SECTIO H \\
\hline
\end{tabular}

Uniwersytet Łódzki. Wydział Ekonomiczno-Socjologiczny

\title{
ALEKSANDRA PIELOCH-BABIARZ
}

aleksandra.pieloch@uni.lodz.pl

\section{Realizacja dtugoterminowych stóp zwrotu z inwestycji w akcje spótek regularnie wypłacających dywidendę}

Achieving Long-term Stock Returns on Shares Regularly Paying Out Dividend

Słowa kluczowe: regularne wypłaty dywidendy; nadzwyczajne stopy zwrotu; inicjowanie i kontynuowanie wypłaty dywidendy

Keywords: regular dividend pay-outs; abnormal returns; dividend initiation and continuation

Kod JEL: G10; G23; G35

\section{Wstęp}

Inwestor giełdowy działa z zamiarem realizacji określonego zwrotu z inwestycji. W przypadku inwestycji w akcje spółek publicznych inwestorzy mają możliwość osiągnięcia korzyści finansowych w postaci zysków kapitałowych i dywidendy. Przyjęcie przez spółkę określonej polityki dywidendy jest strategiczną decyzją mającą wpływ na funkcjonowanie i konkurencyjność przedsiębiorstwa, w tym w szczególności na możliwości inwestycyjne spółki. Realizacja przez spółkę rentownych projektów inwestycyjnych powinna skutkować wzrostem jej wartości rynkowej. Pojawia się zatem pytanie: Czy i w jaki sposób regularne wypłaty dywidendy wpływają na wartość rynkową spółki w długim okresie?

Celem artykułu jest zidentyfikowanie i scharakteryzowanie relacji między prowadzeniem regularnych wypłat dywidendy a kształtowaniem się wartości rynkowej 
spółki w okresie 10 lat od momentu wypłaty dywidendy inicjalnej. Cel ten był możliwy do osiągnięcia w drodze empirycznej weryfikacji hipotezy badawczej stwierdzającej, że im dłużej spółka realizuje politykę regularnych wypłat dywidendy, tym wyższe są nadzwyczajne stopy zwrotu z akcji. Takie sformułowanie hipotezy badawczej jest związane $\mathrm{z}$ występowaniem w literaturze przedmiotu luki badawczej w zakresie możliwości realizacji przez inwestora giełdowego długoterminowego zwrotu z inwestycji w akcje spółek regularnie wypłacających dywidendę.

\section{Reakcja rynku kapitałowego na wypłatę dywidendy - przegląd literatury}

Prowadzone na rynkach światowych badania nad kształtowaniem się kursu rynkowego akcji spółek wypłacających dywidendę koncentrują się głównie na analizie krótkoterminowej reakcji rynku kapitałowego na informację o zmianach w prowadzonej polityce dywidendy, tj. inicjowaniu dywidendy, zwiększaniu bądź zmniejszaniu poziomu wypłaty oraz zaprzestaniu wypłaty dywidendy. W szczególności duża część badań jest poświęcona kształtowaniu się kursu rynkowego akcji po ogłoszeniu decyzji o wypłacie dywidendy inicjalnej (initial dividend, maiden dividend), za którą przyjmuje się pierwszą wypłatę z zysku netto na rzecz akcjonariuszy spółki giełdowej przeprowadzoną przez spółkę po pierwszej ofercie publicznej ${ }^{1}$ [Lipson, Maquieira, Megginson, 1998, s. 38; McCaffrey, Hamill, 2000, s. 533]. Informacja o wypłacie pierwszej dywidendy jest zwykle pozytywnie odbierana przez inwestorów, co jest zgodne z teorią sygnalizacji [Payne, 2011, s. 149; Hobbs, Schneller, 2012, s. 1395]. W okresie okołoogłoszeniowym obserwuje się zazwyczaj wzrost wartości rynkowej spółki. Badania prowadzone z wykorzystaniem skumulowanej ponadprzeciętnej stopy zwrotu z akcji (CAR) wykazały pozytywną reakcję rynku kapitałowego na informację o wypłacie dywidendy inicjalnej zarówno na zagranicznych rynkach kapitałowych [Lacina, Zhang, 2008, s. 201; Sare, Kumak, Salakpi, 2014, s. 440; Goel, 2015, s. 46], jak i na rynku krajowym [Gurgul, Majdosz, 2005, s. 25; Czerwonka, 2010, s. 67; Pieloch-Babiarz, 2016, s. 88; Kaźmierska-Jóźwiak, 2017, s. 169].

Prowadzone na rynkach światowych analizy wykazują, że pozytywna reakcja rynku kapitałowego jest obserwowana także w krótkim okresie po ogłoszeniu przez spółkę decyzji o podwyższeniu wypłaty dywidendy [Dasilas, Leventis, 2011, s. 852; Sare, Kumak, Salakpi, 2014, s. 440]. Natomiast informacja o obniżeniu lub zaprzestaniu wypłaty dywidendy jest negatywnym sygnałem dla inwestorów, co skutkuje zwykle spadkiem kursu rynkowego akcji [Healy, Palepu, 1988, s. 149; Michaely, Thaler, Womack, 1995, s. 573; Kumar, 2017, s. 327]. Negatywna reakcja rynku kapitałowego jest też obserwowana w tzw. dniu odcięcia dywidendy (ex-dividend

1 Niektórzy autorzy za dywidendę inicjalną przyjmują także tę wypłaconą ponownie po 10 latach [Healy, Palepu, 1988, s. 149], podczas gdy inni mówią wtedy o wznowieniu dywidendy (dividend resumption) [Chen, Chou, Lee, 2014, s. 643]. 
day), będącym pierwszym dniem, w którym akcja nie zawiera już w sobie prawa do dywidendy z zysku netto za ostatni rok obrotowy [Borges, 2008, s. 15; Perepeczo, 2014, s. 184].

Badania prowadzone $\mathrm{z}$ uwzględnieniem długiego horyzontu inwestycyjnego (obejmujące okres do 5 lat) nie dostarczają jednoznacznych wyników dotyczących reakcji rynku kapitałowego na regularne wypłaty dywidendy. Niektóre analizy [Hobbs, Schneller, 2012, s. 1395] nie wykazują różnic w wysokości kursu rynkowego akcji spółek dywidendowych i tych niewypłacających dywidendy. Inne badania wskazują z kolei, że w ciągu 5 lat po zainicjowaniu wypłaty dywidendy średnia miesięczna stopa zwrotu jest wyższa w przypadku spółek dywidendowych [How, Ngo, Verhoeven, 2011, s. 267; Nguyen, 2014, s. 583].

\section{Metodyka badań empirycznych}

Badania empiryczne zostały przeprowadzone na grupie spółek notowanych na Giełdzie Papierów Wartościowych w Warszawie w latach 2001-2016. Warunkiem włączenia spółki do badań służących empirycznej weryfikacji postawionej hipotezy badawczej była wypłata przez nią dywidendy inicjalnej w przyjętym okresie analitycznym i jej kontynuacja w postaci regularnych ${ }^{2}$ wypłat dywidendy. Przyjęte kryteria wyboru spełniło 87 spółek $^{3}$. Następnie z próby badawczej usunięto - ze względu na ich specyfikę - instytucje finansowe i spółki, w przypadku których nie udało się pozyskać niezbędnych do badań danych finansowych. Ostatecznie grupę badawczą utworzyło 75 spółek.

Analizy przeprowadzono w trzech etapach. W pierwszej kolejności badane spółki zostały scharakteryzowane pod względem liczby lat regularnych wypłat dywidendy. Następnie, wykorzystując test post-hoc najmniejszej istotnej różnicy (NIR) Fishera [Stanisz, 2007, s. 397], zbadano istotność różnic średnich wartości stopy wypłaty dywidendy (DPR) w celu identyfikacji występowania zależności między regularnością a wysokością wypłaty.

Drugi etap badań został poświęcony kształtowaniu się długoterminowych stóp zwrotu z akcji spółek regularnie wypłacających dywidendę. Badania przeprowadzono w oparciu o metodykę analizy zdarzeń z wykorzystaniem stóp zwrotu osiąganych w związku z realizacją tzw. strategii „kup i trzymaj” (buy \& hold return - BHR). $\mathrm{W}$ badaniach założono strategię inwestycyjną polegającą na zakupie akcji po cenie zamknięcia z dnia powzięcia przez walne zgromadzenie akcjonariuszy uchwały

2 Za regularne wypłaty dywidendy przyjęto, zgodnie z wykorzystywaną od 2016 r. metodologią doboru spółek do portfela indeksu WIGdiv, te spółki, które na przestrzeni pięciu kolejnych lat obrotowych regularnie dokonywały wypłaty dywidendy [www.gpw.pl/Indeks?isin=PL9999999482].

3 Dodać należy, iż w przyjętym okresie analitycznym więcej spółek inicjowało wypłatę dywidendy. Spółki te nie znalazły się jednak w grupie badawczej w związku z brakiem regularności wypłat, co oznacza, że zaprzestały wypłacać dywidendę lub ją zawiesiły w okresie krótszym niż 5 lat obrotowych. 
o wypłacie dywidendy inicjalnej i przyjęciu długiego horyzontu inwestycyjnego (co najmniej 5 lat). Wprowadzenie takich założeń badawczych wyeliminowało wpływ krótkoterminowych wahań kursu giełdowego akcji, a w szczególności wzrostu ceny rynkowej akcji w ostatnich dniach notowań „,z dywidendą" i jej spadku w tzw. dniu odcięcia dywidendy (ex-dividend day), czyli w następnym dniu po ustaleniu praw do dywidendy. W opracowaniu przyjęto 10-letnią perspektywę analityczną ${ }^{4}$.

Nadzwyczajna stopa zwrotu wynikająca z przyjętej strategii inwestycyjnej została wyznaczona z wykorzystaniem poniższych formuł [Michaely, Thaler, Womack, 1995, s. 582]:

$$
\begin{aligned}
& B H A R_{T}^{D I, i}=B H R_{T}^{D I, i}-B H R_{T}^{W I G, i} \\
& B H A R_{T}^{D I, i}=\prod_{t=2}^{T}\left(1+R_{i, t}\right)-\prod_{t=2}^{T}\left(1+R_{W I G, t}\right) \\
& \overline{B H A R_{T}^{D I}}=\frac{1}{n} \sum_{i=1}^{n} B H A R_{T}^{D I, i}
\end{aligned}
$$

gdzie:

$B H A R_{T}^{D I, i}$ - nadzwyczajna stopa zwrotu typu „kup i trzymaj” z akcji $i$-tej spółki inicjującej i regularnie wypłacającej dywidendę w okresie obserwacji $T^{5}$

$B H R_{T}^{D I, i}$ - stopa zwrotu typu „kup i trzymaj” akcji $i$-tej spółki w okresie obserwacji $T$

$B H R_{T}^{W I G, i}$ - stopa zwrotu typu „kup i trzymaj” z indeksu WIG odpowiadająca $i$-tej spółce w okresie obserwacji $T$

$R_{i, t}$ - stopa zwrotu z akcji $i$-tej spółki w dniu notowań $t$

$R_{W I G, t}$ - stopa zwrotu z indeksu WIG w dniu notowań $t$

$\overline{B H A R_{T}^{D}}$ - średnia nadzwyczajna stopa zwrotu typu „kup i trzymaj” dla spółek inicjujących i regularnie wypłacających dywidendę w okresie obserwacji $T$

$n$ - liczba badanych spółek

Istotność statystyczną uzyskanych wyników zbadano, wykorzystując konwencjonalną statystykę $t$ opisaną poniższą formułą [Lyon, Barber, Tsai, 1999, s. 173]:

${ }^{4}$ Mimo że w wybranym okresie analitycznym część spółek wypłacała dywidendę dłużej niż 10 lat, podjęto decyzję o zakończeniu badań w dziesiątym roku po wypłacie dywidendy inicjalnej w związku z występowaniem dużych dysproporcji w liczbie badanych przypadków wypłaty dywidendy w kolejnych latach.

5 Stopy zwrotu BHR i BHAR wyraża się - podobnie jak inne stopy zwrotu - w ujęciu procentowym. 


$$
t=\frac{\overline{B H A R_{T}^{D I}}}{\sigma\left(B H A R_{T}^{D I}\right) / \sqrt{n}}
$$

gdzie:

$\sigma\left(B H A R_{T}^{D I}\right)$ - odchylenie standardowe nadzwyczajnych stóp zwrotu typu „kup i trzymaj" (pozostałe oznaczenia - jak wyżej)

Trzeci etap badań posłużył zidentyfikowaniu i scharakteryzowaniu relacji między liczbą lat regularnych wypłat dywidendy a kształtowaniem się wysokości nadzwyczajnej stopy zwrotu typu „kup i trzymaj” $\left(B H A R_{T}^{D, i}\right)$. W tym celu oszacowano metodą najmniejszych kwadratów parametry modelu regresji wielorakiej w postaci:

$$
\begin{aligned}
B H A R_{T}^{D I, i}= & \hat{a}_{0}+\hat{a}_{1} T I M E_{T, i}+\hat{a}_{2} \Delta R O A_{T, i}+\hat{a}_{3} \Delta C R_{T, i}+\hat{a}_{4} \Delta D R_{T, i} \\
& +\hat{a}_{5} \Delta \ln T C_{T, i}+\hat{a}_{6} \Delta I N V_{T, i}+\grave{a}_{i}
\end{aligned}
$$

gdzie:

$T I M E_{T, i}-$ liczba lat regularnych wypłat dywidendy przez $i$-tą spółkę w okresie $T$

$\triangle R O A_{T, i}$-zmiana współczynnika rentowności aktywów całkowitych $i$-tej spółki w okresie $T(\mathrm{w} \%)$

$\Delta C R_{T, i}$-zmiana współczynnika płynności bieżącej $i$-tej spółki w okresie $T(\mathrm{w} \%)$

$\Delta D R_{T, i}-$ zmiana stopy zadłużenia $i$-tej spółki w okresie $T$ (w \%)

$\Delta \ln T C_{T, i}-$ zmiana wielkości przedsiębiorstwa mierzonej logarytmem z aktywów całkowitych $i$-tej spółki w okresie $T$ (w \%)

$\triangle I N V_{T, i}$-zmiana wielkości inwestycji $i$-tej spółki w okresie $T(\mathrm{w} \%)$

Zmienne opisujące sytuację finansową spółki włączono do modelu jako zmienne kontrolne ${ }^{6}$.

Wykorzystane w badaniu dane pozyskano z bazy Notoria Serwis, portalu Infostrefa.com i Roczników Giełdowych. Analizy przeprowadzono z użyciem programu Statistica.

\section{Rezultaty badań empirycznych}

W latach 2001-2016 liczba spółek notowanych na GPW w Warszawie, które wypłaciły dywidendę, zwiększyła się ponad trzykrotnie (tj. z 62 do 199 spółek). Średnioroczne tempo wzrostu liczby spółek dywidendowych wyniosło w okresie

${ }^{6}$ Za zmienne kontrolne przyjęto najczęściej wskazywane w literaturze przedmiotu determinanty polityki wypłaty dywidendy [DeAngelo, DeAngelo, 2007, s. 11; Eije, Megginson, 2008, s. 347]. 
objętym analizą 8,71\%. Najwięcej spółek wypłaciło dywidendę w 2016 r., w którym spółki dywidendowe stanowiły 40,86\% wszystkich spółek giełdowych.

Kierując się kryterium regularności wypłat dywidendy, zauważono, iż w każdym roku okresu badawczego dominowały nieregularne wypłaty dywidendy, jednakże udział spółek regularnie wypłacających dywidendę wzrastał (z 16,46\% spółek dywidendowych w 2005 r. do 34,67\% w 2016 r.). W przyjętym okresie analitycznym 87 spółek zainicjowało dywidendę i kontynuowało wypłatę przez co najmniej 5 lat po dywidendzie inicjalnej. Wśród nich dominowały te, które wypłaciły dywidendę pięciokrotnie ( $25,29 \%$ spółek), natomiast najmniej spółek (3,45\%) wypłaciło dywidendę dziewięciokrotnie. Ponadto $21,84 \%$ badanych spółek wypłaciło dywidendę w każdym z co najmniej dziesięciu lat następujących po wypłacie dywidendy inicjalnej (tab. 1). Dodać należy, iż wśród nich przeważały spółki wypłacające dywidendę w ciągu szesnastu i dwunastu kolejnych lat (po 6 spółek).

Tab. 1. Liczba i udział spółek giełdowych inicjujących dywidendę i regularnie kontynuujących jej wypłatę w latach 2001-2016

\begin{tabular}{|l|c|c|}
\hline $\begin{array}{c}\text { Liczba lat regularnych wypłat } \\
\text { dywidendy }\end{array}$ & Liczba spółek & Udział spółek (\%) \\
\hline 5 & 22 & 25,29 \\
\hline 6 & 14 & 16,09 \\
\hline 7 & 18 & 20,69 \\
\hline 8 & 11 & 12,64 \\
\hline 9 & 3 & 3,45 \\
\hline 10 i więcej & 19 & 21,84 \\
\hline Razem & 87 & 100,00 \\
\hline
\end{tabular}

Źródło: opracowanie własne na podstawie: [Roczniki Giełdowe].

Zaobserwowano, że wraz z wydłużaniem się okresu regularnych wypłat dywidendowych spółki przeznaczały na dywidendę coraz większą część zysku netto. W pierwszym roku realizacji wypłat dywidendy spółki przekazywały właścicielom średnio $52,54 \%$ zysku netto. W kolejnych latach stopa wypłaty dywidendy rosła, by osiągnąć najwyższy poziom w siódmym i ósmym roku po zainicjowaniu dywidendy ${ }^{7}$ (odpowiednio 120,99\% i 122,09\% ${ }^{8}$ ). Analiza istotności różnic średnich wartości stopy wypłaty dywidendy wykazała występowanie pewnych zależności między liczbą lat realizacji regularnych wypłat a wysokością dywidendy. Średnie wartości DPR uzyskane dla siódmego i ósmego roku analizy różniły się istotnie od średnich wyników uzyskanych w większości pozostałych lat (tab. 2).

\footnotetext{
7 Sytuacja ta może świadczyć o realizacji regularnych wypłat dywidendy m.in. przez spółki duże, dojrzałe, stabilne finansowo czy posiadające mniejsze możliwości efektywnego zaangażowania kapitału.

8 Środki na wypłatę dywidendy pochodziły m.in. z kapitału zapasowego i kapitałów rezerwowych.
} 
Pobrane z czasopisma Annales H - Oeconomia http://oeconomia.annales.umcs.pl Data: 26/04/2023 15:29:57

REALIZACJA DŁUGOTERMINOWYCH STÓP ZWROTU Z INWESTYCJI W AKCJE...

Tab. 2. Wyniki testu post-hoc najmniejszej istotnej różnicy Fishera dla średnich wartości stopy wypłat dywidendy względem liczby lat regularnych wypłat dywidendy

\begin{tabular}{|c|c|c|c|c|c|c|c|c|c|c|}
\hline Rok & 1 & 2 & 3 & 4 & 5 & 6 & 7 & 8 & 9 & 10 \\
\hline \multicolumn{11}{|c|}{ Średnia wartość stopy wypłat dywidendy DPR (\%) } \\
\hline & 52,54 & 63,72 & 61,96 & 68,45 & 68,73 & 84,77 & 120,99 & 122,09 & 89,90 & 82,10 \\
\hline \multicolumn{11}{|c|}{ Wyniki testu NIR Fishera (p-value) } \\
\hline 1 & - & - & - & - & - & - & - & - & - & - \\
\hline 2 & 0,57 & - & - & - & - & - & - & - & - & - \\
\hline 3 & 0,63 & 0,93 & - & - & - & - & - & - & - & - \\
\hline 4 & 0,42 & 0,81 & 0,74 & - & - & - & - & - & - & - \\
\hline 5 & 0,40 & 0,79 & 0,72 & 0,99 & - & - & - & - & - & - \\
\hline 6 & 0,13 & 0,32 & 0,27 & 0,44 & 0,43 & - & - & - & - & - \\
\hline 7 & 0,01 & 0,01 & 0,01 & 0,02 & 0,02 & 0,13 & - & - & - & - \\
\hline 8 & 0,01 & 0,03 & 0,02 & 0,04 & 0,04 & 0,18 & 0,97 & - & - & - \\
\hline 9 & 0,25 & 0,42 & 0,39 & 0,51 & 0,51 & 0,88 & 0,37 & 0,38 & - & - \\
\hline 10 & 0,41 & 0,60 & 0,57 & 0,70 & 0,70 & 0,94 & 0,30 & 0,31 & 0,86 & - \\
\hline
\end{tabular}

Źródło: opracowanie własne na podstawie: [Notoria Serwis].

Stopa zwrotu typu „kup i trzymaj” z akcji spółek, które regularnie (tj. w każdym roku przez co najmniej pięć kolejnych lat po zainicjowaniu wypłaty dywidendy) dzieliły się z akcjonariuszami zyskiem netto, była wyższa niż stopa zwrotu $B H R_{T}$ realizowana $z$ indeksu WIG. Świadczą o tym dodatnie wartości średnich nadzwyczajnych stóp zwrotu uzyskanych w każdym z dziesięciu okresów obserwacji $\left(\overline{B H A R_{T}}>0\right)$. Ponadto w ciągu sześciu pierwszych lat po wypłacie dywidendy inicjalnej wysokość średnich nadzwyczajnych stóp zwrotu wzrastała. Na koniec roku, w którym spółki po raz pierwszy wypłaciły dywidendę, $\overline{B H A R_{T}}$ ukształtowała się na poziomie $0,41 \%$, by w szóstym roku wypłat wzrosnąć do poziomu 7,32\% (istotność statystyczna na poziomie $\alpha=0,01)$. Największy wzrost średnich nadzwyczajnych stóp zwrotu nastąpił po dwóch, a następnie po pięciu latach wypłat dywidendy. Stopa $B H A R_{2 Y}$ była ponad

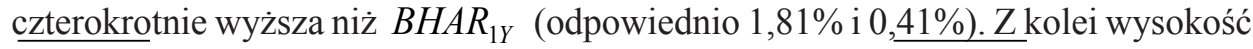
$B_{B H A R_{5 Y}}$ przewyższyła więcej niż dwukrotnie wysokość $B H A R_{4 Y}$ (odpowiednio $6,73 \%$ i $2,96 \%$ ). Również wartości mediany nadzwyczajnych stóp zwrotu były w tych latach wysokie, gdyż wyniosły $0,90 \%$ i 0,97\%. Przyczyn takiego kształtowania się średniej nadzwyczajnej stopy zwrotu można upatrywać nie tylko w reakcji rynku kapitałowego na zainicjowanie wypłat dywidendy, ale również - w szczególności w przypadku piątego roku wypłaty dywidendy - w zachowaniu się tej grupy długoterminowych inwestorów giełdowych, którzy preferują inwestycje w spółki dywidendowe. Dla tych inwestorów otrzymywanie regularnych dochodów w postaci dywidendy jest jednym z kluczowych kryteriów wyboru inwestycji. Można przypuszczać, iż wypłata dywidendy następująca piąty z kolei rok jest odbierana przez inwestorów giełdowych jako ważny sygnał potwierdzający realizację przez spółkę polityki regularnych wypłat dywidendy. Informacja ta skutkuje ponadprzeciętną pozytywną reakcją rynku kapitałowego, co uwidacznia się w wysokich wartościach nadzwyczajnych stóp zwrotu po pięciu latach wypłaty dywidendy. Jednakże należy 
zauważyć, iż po pewnym czasie słabnie efekt inicjowania i prowadzenia regularnych wypłat dywidendy. W badanej grupie spółek obniżenie się średnich nadzwyczajnych stóp zwrotu zaobserwowano po siedmiu i dziesięciu latach wypłaty dywidendy, kiedy wysokość $B H A R_{T}$ spadła odpowiednio do 5,38\% i 2,89\% (w tym przypadku uzyskany wynik nie był jednak istotny statystycznie) (tab. 3).

Tab. 3. Statystyki opisowe nadzwyczajnych stóp zwrotu związanych z realizacją strategii inwestycyjnej „kup i trzymaj” w kolejnych latach po wypłacie dywidendy inicjalnej

\begin{tabular}{|l|c|c|c|c|c|c|}
\hline \multicolumn{1}{|c|}{ Spec. } & Średnia & Mediana & $\begin{array}{c}\text { Odchylenie } \\
\text { standardowe }\end{array}$ & Min. & Max & N \\
\hline BHAR $_{1 \mathrm{Y}}$ & $0,41 * * *$ & 0,21 & 0,71 & $-0,97$ & 2,79 & 75 \\
\hline $\mathrm{BHAR}_{2 \mathrm{Y}}$ & $1,81 * * *$ & 0,90 & 2,78 & $-1,45$ & 10,76 & 75 \\
\hline $\mathrm{BHAR}_{3 \mathrm{Y}}$ & $2,66 * * *$ & 0,83 & 0,83 & $-7,78$ & 21,78 & 75 \\
\hline $\mathrm{BHAR}_{4 \mathrm{Y}}$ & $2,96 * * *$ & 0,58 & 5,68 & $-2,19$ & 31,28 & 75 \\
\hline $\mathrm{BHAR}_{5 \mathrm{Y}}$ & $6,73 * * *$ & 0,97 & 13,96 & $-1,66$ & 61,96 & 75 \\
\hline $\mathrm{BHAR}_{6 \mathrm{Y}}$ & $7,32 * * *$ & 0,67 & 14,98 & $-2,21$ & 68,30 & 51 \\
\hline $\mathrm{BHAR}_{7 \mathrm{Y}}$ & $5,38 * *$ & 0,31 & 11,01 & $-1,23$ & 46,09 & 40 \\
\hline $\mathrm{BHAR}_{8 \mathrm{Y}}$ & $8,98 * * *$ & 0,48 & 14,02 & $-0,70$ & 46,24 & 27 \\
\hline $\mathrm{BHAR}_{9 \mathrm{Y}}$ & $10,62 *$ & 4,39 & 19,44 & $-0,48$ & 61,87 & 19 \\
\hline $\mathrm{BHAR}_{10 \mathrm{Y}}$ & 2,89 & 0,03 & 4,92 & $-0,62$ & 12,71 & 16 \\
\hline
\end{tabular}

$*, * *, * *$ - istotność statystyczna na poziomie odpowiednio $10 \%, 5 \%$ i $1 \%$

Źródło: opracowanie własne na podstawie: [Infostrefa; Roczniki Giełdowe].

Wyniki estymacji modelu regresji wielorakiej wskazują na występowanie istotnej statystycznie zależności między liczbą lat, w których spółki regularnie dzieliły się $\mathrm{z}$ akcjonariuszami wypracowanym zyskiem netto, a kształtowaniem się nadzwyczajnych stóp zwrotu związanych z realizacją strategii inwestycyjnej typu „kup i trzymaj”. Wartość parametru przy zmiennej objaśniającej $T I M E_{T, i}$ wyniosła 0,24 $i$ była istotna statystycznie na poziomie istotności $\alpha=0,01$. Można zatem stwierdzić, że wraz z wydłużaniem się czasu realizacji regularnych wypłat dywidendy o jeden rok, wartość $B H A R_{T}$ wzrastała o 0,24 p.p. (tab. 4).

Tab. 4. Wyniki estymacji modelu regresji wielorakiej dla zmiennej objaśnianej $B H A R_{T}$

\begin{tabular}{|c|c|c|c|c|}
\hline Zmienne objaśniające & Parametr $\beta_{i}$ & Współczynnik $R^{2}$ & Statystyka $F$ & $\mathrm{p}$-value \\
\hline Wyraz wolny & 0,86 & \multirow{7}{*}{0,07} & \multirow{7}{*}{4,15} & \multirow{7}{*}{$<0,01$} \\
\hline TIME $_{\mathrm{T}, \mathrm{i}}$ & $0,24 * * *$ & & & \\
\hline$\Delta R O A_{T, i}$ & 0,01 & & & \\
\hline$\Delta C R_{T, i}$ & $-0,01$ & & & \\
\hline$\Delta D R_{T, i}$ & $-0,09 *$ & & & \\
\hline$\Delta \ln T C_{T, i}$ & 0,04 & & & \\
\hline$\Delta I N V_{T, i}$ & $-0,06$ & & & \\
\hline
\end{tabular}

$*, * * *$ - istotność statystyczna na poziomie odpowiednio $10 \%$ i $1 \%$

Źródło: opracowanie własne na podstawie: [Notoria Serwis; Roczniki Giełdowe]. 
Wśród zmiennych kontrolnych modelu jedynie wartość parametru przy zmiennej $\Delta D R_{T, i}$ była istotna statystycznie $(\alpha=0,1)$. Wraz ze wzrostem dynamiki stopy zadłużenia spółki o 1 p.p. wysokość nadzwyczajnej stopy zwrotu malała w modelu o 8,8 p.p. ${ }^{9}$ Ponadto współczynnik determinacji wyniósł 0,07 , a więc całkowita zmienność zmiennej objaśnianej $B H A R_{T}$ została wytłumaczona zmiennością zmiennych objaśniających w $7 \%{ }^{10}$.

\section{Podsumowanie}

Badania przeprowadzone na spółkach warszawskiej giełdy, które w latach 20012016 zainicjowały dywidendę, a następnie regularnie kontynuowały jej wypłatę, pozwoliły na wyprowadzenie następujących wniosków. Po pierwsze, w kolejnych latach regularnych wypłat dywidendy spółki przekazywały akcjonariuszom coraz większą część zysku netto. Po drugie, stopa zwrotu związana z realizacją strategii inwestycyjnej typu „kup i trzymaj” dla spółek regularnie wypłacających dywidendę była wyższa niż stopa zwrotu $B H R_{T}$ z indeksu WIG. Po trzecie, prowadzenie regularnych wypłat dywidendy skutkowało szczególnie silną reakcją rynku kapitałowego w drugim i piątym roku wypłaty. Po czwarte, wraz ze wzrostem liczby lat regularnych wypłat dywidendy nadzwyczajna stopa zwrotu typu „kup i trzymaj” wzrastała.

Należy uznać, że zaprezentowane w opracowaniu wyniki badań mają charakter wstępnych prac prowadzonych nad problematyką kształtowania się długoterminowych stóp zwrotu z inwestycji w akcje spółek regularnie dzielących się z właścicielami wypracowanym zyskiem netto. Istnieje konieczność rozszerzenia badań z uwzględnieniem innych czynników realizacji zwrotu z inwestycji, w tym np. prowadzenia określonej polityki wypłat dywidendy. Ponadto wydaje się, że warto również podjąć badania w kontekście podziału dywidendy na tę wypłacaną przez spółki Skarbu Państwa, gdzie wypłata dywidendy jest głównie kwestią polityczną (zasilenie budżetu), w stosunku do spółek prywatnych, gdzie jest to kwestia ekonomiczna.

9 Uzyskane rezultaty badań są zgodne z przedstawianym w literaturze naukowej poglądem, że wzrost zadłużenia, zwiększając koszty pozyskania źródeł finansowania spółki i ryzyko jej działalności, negatywnie wpływa na wysokość wypłaty dywidendy. Spółki charakteryzujące się wysokim poziomem zadłużenia wykazują mniejszą skłonność do wypłaty dywidendy, wykorzystując zyski netto do spłaty swoich zobowiązań [Jensen, Solberg, Zorn, 1992, s. 247]. Zmniejszenie wypłaty dywidendy lub jej zaprzestanie może prowadzić natomiast do spadku wartości rynkowej spółki [Michaely, Thaler, Womack, 1995, s. 573].

${ }^{10} \mathrm{~W}$ modelu z dwiema zmiennymi ( $\mathrm{tj} . T I M E_{T, i}$ i $\Delta D R_{T, i}$ ) wartości parametrów przy tych zmiennych wyniosły odpowiednio 1,06 i -0,36. Oszacowano także dwa alternatywne modele regresji liniowej, w których - oprócz zmiennej $T I M E_{T, i}$ - znalazły się także zmienne kontrolne $\left(R O A_{T, i}, C R_{T, i}, D R_{T, i}, \ln T C_{T, i} I N T_{T, i}\right)$ będące charakterystykami finansowymi $i$-tej spółki odpowiednio na początku i na końcu roku, w którym wypłacono dywidendę. Oszacowane wartości parametrów pierwszego modelu wykazały dodatni związek między zmienną $B H A R_{T}$ a zmienną objaśniającą $T I M E_{T, i}$ i $R O A_{T, i}$ oraz negatywny związek między zmienną objaśnianą a zmienną $\ln T C_{T, i}$ (poziom istotności odpowiednio $\alpha=0,01$ i $\alpha=0,05$ ). $Z$ kolei $\mathrm{w}$ drugim $\mathrm{z}$ tych modeli zaobserwowano dodatni związek między $B H A R_{T}$ a zmienną $T I M E_{T, i}$ oraz $R O A_{T, i}$ (poziom istotności odpowiednio $\alpha=0,01$ i $\alpha=0,05$ ). 


\section{Bibliografia}

Borges M., The Ex-Dividend Day Stock Price Behavior: The Case of Portugal, "Atlantic Economic Journal" 2008, Vol. 36(1), DOI: https://doi.org/10.1007/s11293-007-9104-8.

Chen S.S., Chou R.K., Lee Y.C., The Long-term Performance Following Dividend Initiations and Resumptions Revisited, "Journal of Economics and Finance" 2014, Vol. 38.

Czerwonka L., Wpływ zainicjowania wypłaty dywidendy na cenę akcji spótki, „Zeszyty Naukowe Uniwersytetu Szczecińskiego" 2010, nr 634.

Dasilas A., Leventis S., Corrigendum to 'Stock market reaction to dividend announcements: Evidence from the Greek stock market', "International Review of Economics and Finance" 2011, Vol. 20(4), DOI: https://doi.org/10.1016/j.iref.2011.03.001.

DeAngelo H., DeAngelo L., Payout policy pedagogy: What matters and why, "European Financial Management" 2007, Vol. 13(1), DOI: https://doi.org/10.1111/j.1468-036X.2006.00283.x.

Eije H., Megginson W.L., Dividends and Share Repurchases in European Union, "Journal of Financial Economics" 2008, Vol. 89(2).

Goel S., Dividend Policy and Market Price Behaviour in Indian Companies, "Skyline Business Journal" 2015, Vol. 11(1).

Gurgul H., Majdosz P., Effect of Dividend and Repurchase Announcements on the Polish Stock Market, „Badania Operacyjne i Decyzji” 2015, nr 1.

Healy P.M., Palepu K.G., Earnings Information Conveyed by Dividend Initiations and Omissions, "Journal of Financial Economics" 1988, Vol. 21(2), DOI: https://doi.org/10.1016/0304-405X(88)90059-1.

Hobbs J., Schneller M.I., Dividend Signalling and Sustainability, "Applied Financial Economics" 2012, Vol. 22(17), DOI: https://doi.org/10.1080/09603107.2012.654909.

How J., Ngo K., Verhoeven P., Dividend initiations and long-run IPO performance, “Australian Journal of Management” 2011, Vol. 36(2), DOI: https://doi.org/10.1177/0312896211405569.

Infostrefa, http://infostrefa.com [dostęp: 23.01.2018].

Jensen G.R., Solberg D.P., Zorn T.S., Simultaneous Determination of Insider Ownership, Debt and Dividend Policies, "The Journal of Financial and Quantitative Analysis" 1992, Vol. 27(2),

DOI: https://doi.org/10.2307/2331370.

Kaźmierska-Jóźwiak B., W poszukiwaniu przyczyn inicjowania dywidend, „Annales UMCS. Sectio H” 2017, nr 5, DOI: https://doi.org/10.17951/h.2017.51.5.169.

Kumar S., New Evidence on Stock Market Reaction to Dividend Announcements in India, "Research in International Business and Finance" 2017, Vol. 39.

Lacina M., Zhang Z., Dividend Initiations by High-Tech Firms, "Review of Pacific Basin Financial Markets \& Policies" 2008, Vol. 11(2), DOI: https://doi.org/10.1142/S0219091508001325.

Lipson M.L., Maquieira C.P., Megginson W., Dividend Initiations and Earnings Surprises, "Financial Management" 1998, Vol. 3, DOI: https://doi.org/10.2307/3666273.

Lyon J.D., Barber B.M., Tsai C.L., Improved Methods for Tests of Long-Run Abnormal Stock Returns, "The Journal of Finance" 1999, Vol. 54(1), DOI: https://doi.org/10.1111/0022-1082.00101.

McCaffrey K., Hamill P., Dividend Initiation Announcement Effects in Initial Public Offerings, "Applied Financial Economics" 2000, Vol. 10(5), DOI: https://doi.org/10.1080/096031000416415.

Michaely R., Thaler R.H., Womack K.L., Price Reactions to Dividend Initiations and Omissions: Overreaction or Drift?, "The Journal of Finance" 1995, Vol. 50(2),

DOI: https://doi.org/10.1111/j.1540-6261.1995.tb04796.x.

Nguyen K.H., Impact of a Dividend Initiation Wave on Shareholder Wealth, "Applied Financial Economics" 2014, Vol. 24(8), DOI: https://doi.org/10.1080/09603107.2014.892197.

Notoria Serwis, http://ir.notoria.pl [dostęp: 20.01.2018].

Payne B., On the financial characteristics of firms that initiated new dividends during a period of economic recession and financial market turmoil, "Journal of Economics and Finance" 2011, Vol. 35(2),

DOI: https://doi.org/10.1007/s12197-009-9084-4. 
Perepeczo A., Reakcja inwestorów na decyzje o wypłacie dywidendy a kryzys finansowy, „Prace Naukowe Uniwersytetu Ekonomicznego we Wrocławiu” 2014, nr 326.

Pieloch-Babiarz A., Reakcja rynku kapitałowego na wypłatę dywidendy inicjalnej w świetle cateringowej teorii dywidendy, ,Studia Ekonomiczne. Zeszyty Naukowe UE w Katowicach” 2016, nr 263.

Roczniki Giełdowe, 2002-2017, www.gpw.pl/biblioteka-gpw-lista?gpwlc_id=10 [dostęp: 15.01.2018].

Sare Y.A., Kumak S.P., Salakpi A., Market Reaction to Dividend Initiation Announcements on the Ghana Stock Exchange: The Case of Industrial Analysis, "Asian Economic and Financial Review" 2014, Vol. 4(4).

Stanisz A., Przystepny kurs statystyki z zastosowaniem STATISTICA PL na przykładach z medycyny, t. 2, StatSoft Polska, Kraków 2007.

www.gpw.pl/Indeks?isin=PL9999999482 [dostęp: 28.04.2018].

\section{Achieving Long-term Stock Returns on Shares Regularly Paying Out Dividend}

The aim of this paper is to identify and characterize the relationship between conducting regular dividend payments and shaping the market value of the company within 10 years from the dividend initiation. The research hypothesis states that the longer time of regular dividend pay-outs, the higher abnormal rates of return. Empirical research shows that buy-and-hold abnormal return (BHAR) calculated for companies regularly paying out dividend is higher than the buy-and-hold abnormal return from the WIG index, and that along with an increase in the number of years of regular dividend payments BHAR increases.

\section{Realizacja długoterminowych stóp zwrotu z inwestycji w akcje spółek regularnie wypłacających dywidendę}

Celem artykułu jest zidentyfikowanie i scharakteryzowanie relacji między prowadzeniem regularnych wypłat dywidendy a kształtowaniem się wartości rynkowej spółki w okresie dziesięciu lat od momentu wypłaty dywidendy inicjalnej. Hipoteza badawcza stanowi, że im dłużej spółka realizuje politykę regularnych wypłat dywidendy, tym wyższe są nadzwyczajne stopy zwrotu z akcji. Badania wykazały, że średnia stopa zwrotu BHAR dla spółek regularnie wypłacających dywidendę jest wyższa niż stopa zwrotu z indeksu WIG oraz że wraz ze wzrostem liczby lat regularnych wypłat dywidendy nadzwyczajna stopa zwrotu wzrasta. 